\title{
The Effect of Training on Medication Adherence of Patients with Hypertension*
}

\author{
Hipertansiyon Hastalarının İlaç Tedavisine Uyumlarında Eğitimin Etkisi
}

\author{
Duygu Akça', Sevda Eliș Yıldız \\ ${ }^{1}$ Department of Nursing, Faculty of Health Sciences, ${ }^{2}$ Department of Midwifery, Faculty of Health Sciences, Kafkas University, \\ Kars, Turkey
}

\begin{abstract}
Aim: In this study, it was aimed to examine the effectiveness of the training on medication adherence to be provided for the patients with hypertension.
\end{abstract}

Material and Method: The study was conducted with 70 patients with hypertension, who applied to Yenișehir Family Health Center between April 2014 and March 2015 and were registered. A descriptive questionnaire involving the socio-demographic characteristics of patients and general information about their diseases, and Morisky Medication Adherence scale (MMAS -8-Items) were used to collect the data. The pretest was firstly performed to the patients about their medication adherence and hypertension disease. Then, they were trained with the training form prepared by the researcher about the drug use and general information and training brochures prepared by the researcher were handed out in order to ensure the permanence of the training. Afterwards, the posttest was carried out to assess the effectiveness of the training.

Results: Evaluating the adherence to medication in patients with hypertension before and after the training according to Morisky Medication Adherence scale; It was found out that the lower adherence decreased to $10.0 \%$ and the moderate adherence decreased to $32.9 \%$ after the training; whereas, the higher adherence increased in more than half (57.1\%). Additionally, the statistical analysis revealed that there was a considerable increase between mean score (5.22 \pm 1.30$)$ of Morisky Medication Adherence scale before the training and its mean score $(7.17 \pm 1.21)$ after the training and the difference between them was statistically significant at advanced level $(p<0.001)$.

Conclusion: In this study, it was determined that the training on medication adherence provided for the patients with hypertension was effective on the patients.

Key words: hypertension; health training; medication adherence

\section{ÖZET}

Amaç: Bu çalıșmada hipertansiyon hastalarına ilaç tedavisine uyum konusunda verilecek eğitimin etkinliğinin incelenmesi amaçlandı.

Materyal ve Metot: Çalıșma, Nisan 2014 - Mart 2015 tarihleri arasında Yenișehir Aile Sağlığı Merkezi'ne bașvuran ve kayıt altına alınan ve hipertansiyonu olan 70 hasta ile gerçekleștirildi. Verilerin toplanmasında hastaların sosyo-demografik özelliklerini ve hastalıkları hakkında genel bilgileri ve Morisky İlaç Uyumu Ölçeğini (MMAS -8-Öğeleri) içeren tanımlayıcı bir anket kullanılmıștır. Ön testen sonra hastalara ilaç uyumu ve hipertansiyon hastalığı hakkında bilgi verilmiș ve ilaç kullanımı ile eğitimin sürekliliğini sağlamak amacıyla araștırmacı tarafından olușturulan genel bilgilendirme broșürleri dağıtılmıștır. Daha sonra eğitimin etkinliğini değerlendirmek için son test uygulanmıștır.

Bulgular: Hipertansiyon hastalarının Morisky ilaç tedavisine uyum ölçeğine göre eğitim öncesi ve eğitim sonrası ilaç tedavisine uyumları değerlendirildiğinde eğitim öncesi \%35.7'sinin ilaç tedavisine düșük derecede, \%64.3'ünün orta derecede uyum gösterdiği saptandı. Eğitim sonrası düșük derecede uyumun \%10.0'a orta derecede uyumun \%32.9'a düștügü yüksek derecede uyumun yarıdan fazla (\%57.1) arttığı tespit edilmiștir, Ayrıca yapılan istatistiksel analizde ise Morisky ilaç tedavisine uyum ölçeği eğitim öncesi puan ortalaması $(5.22 \pm 1.30)$ ile eğitim sonrası puan ortalaması $(7.17 \pm 1.21)$ arasında önemli derecece de artıș olduğu ve aradaki farkın istatistiksel olarak ileri derecede anlamlı olduğu saptandı $(p<0.001)$.

Sonuç: Yapılan bu çalıșmada hipertansiyon hastalarına verilen ilaç tedavisine uyum konusundaki eğitimin hastalar üzerinde etkili olduğu tespit edilmiștir.

Anahtar kelimeler: hipertansiyon; sağık eğitimi; ilaç uyumu

Iletișim/Contact: Sevda Eliş Yıldız, Kafkas Üniversitesi Sağlık Bilimleri Fakültesi Ebelik Bölümü, 36100, Kars, Türkiye • Tel: 04742251567 • E-mail: sevdaelis36@hotmail.com • Geliș/Received:11.03.2019 • Kabul/Accepted: 12.07.2019

ORCID: Duygu Akça, 0000-0003-3952-6328 • Sevda Eliş Yuldiz, 0000-0002-3585-6648

* This study was summarized from Master thesis of first author 


\section{Introduction}

Hypertension is one of the leading health problems of developing and developed countries. The studies have shown that cardiovascular morbidity and mortality are closely related to systolic and diastolic blood pressure $^{1}$. The aim of hypertension treatment is to reduce morbidity and mortality along with cardiovascular diseases. The World Health Organization (WHO) states that hypertension which has a high prevalence is the top among the preventable death causes in the world ${ }^{2}$. It is known that around 1 billion people worldwide are patients with high blood pressure ${ }^{3}$. The growing population of the world means that the number of hypertension patients will increase, thus showing that the disease will be a major public health problem both economically and socially ${ }^{3,4}$. WHO shows that hypertension is one of the leading causes of death of cardiovascular system diseases covering $20-50 \%$ of all deaths and seen as a result of cardiovascular diseases in the developing countries ${ }^{5}$. Hypertension is damaging many organs in the body. However, increasing of the patient's adherence to the illness and the treatment provided provides great benefit in minimizing the possible damages ${ }^{6}$. One of the most important reasons for normal blood pressure level and prevention of the risk of heart diseases in hypertension is the patients' compliance to the given antihypertensive drug treatment ${ }^{7}$.

The World Health Organization reports that half of hypertension patients stop receiving services related to hypertension within the first year after diagnosis, and only half of prescription drugs are taken by those whose medical follow-up is continuing ${ }^{8-10}$. It has been determined that a significant part of hypertension patients are not aware of and diagnosed with the blood pressure illness and most of those who have been diagnosed are not under treatment and control ${ }^{11}$. The main reason for why the blood pressure is not at the desired level is not following the antihypertensive drug treatment. In managing blood pressure effectively, compliance to the pharmacological and non-pharmacological treatment is essential ${ }^{12}$. The thought of "I am healed now" since the blood pressure maintains at the normal level, failure of prescribing the drugs when they are over or having no desire to use them are among the reasons why patients do not use their medication regularly ${ }^{13}$.

It is very important to train and inform the patients and their families in increasing the medication adherence. One of the ways to increase adherence is the involvement of patients in decisions about treatment strategies ${ }^{14}$. Patients and their families should be trained and informed about the disease and the patients should be encouraged to regularly monitor their blood pressures. Whenever the patients come to the control, their medication and non-pharmacological therapies should be evaluated, the patients should be encouraged about the adherence while being in contact with the healthcare professionals.

For this reason, the aim of this study is to help increasing the medication adherence in patients and taking their blood pressures under control by eliminating the lack of information, which is one of the reasons affecting the adherence to treatment in hypertension patients, with a training program. This study is considered to be important as the study has been conducted in a city located in the eastern Turkey and no study has been found on the medication adherence of the individuals.

\section{Material and Method}

\section{Type of Study}

This study was designed as a pre-test and post-test and quasi-experimental study to determine the effect of the health training on the medication adherence of the hypertension patients. In this center, where the study was conducted, the diagnosis, treatment and follow-up for the patients with hypertension are made by the physician of the center. In this center, other than the drug therapy, non-pharmacological therapies are suggested very briefly. For this reason, the study was conducted as a quasi-experimental study.

\section{Ethical Aspect of the Study}

In order to conduct the study, necessary permissions were obtained from the center, where the study would take place, with the ethical approval taken from Ethics Committee of Health Research and Application Hospital of Kafkas University in Kars province (No: 2014/04). In addition, written permission was obtained from Donald E. Morisky to use the Morisky Medication Adherence Scale (MMAS-8-Items).

Patients with hypertension included in the study were informed about the reason for conducting the study, the study plan, and the benefits of the training and they were asked verbally whether or not they wanted to participate in the study or not and those who were willing to participate in the study were included in the study by obtaining their written permissions. 
The training program included hypertension and risk factors, life-styles and drug therapy. In discussing the subjects, the interactive training methods such as explanation, question-answer, discussion, and demonstration were used. The training room of the center was used as the training environment. After the individual training sessions, the reasons for nonadherence were discussed with the patients who did not adhere to the therapy, the individual targets were determined and it was aimed to accomplish these targets.

\section{Hypotheses of the Study}

$\mathrm{H} 0=$ The training given does not change the medication adherence of the patients.

$\mathrm{H} 1=$ The training given increases the medication adherence of the patients.

\section{Population/Sample of the Study}

The study was conducted on 70 patients with hypertension who applied to and registered in the Yenişehir Family Health Center affiliated to city center of Kars. The study was conducted between March 2014 and March 2015. Yenişehir Family Health Center was preferred since it is more crowded than the other regions in terms of density and it is a convenient area for transportation. The sample of the study consisted of patients who applied to health center and enrolled in family physicians on the dates of the study, no selection method was used in the selection of the sample, and the patients who were reached and met the study criteria during the study were included in the study. The sample of the study was composed of the patients who applied to the health center between the study dates and were registered by the family physicians, no selection method was used for the sample selection, the patients who met the inclusion criteria and were reached during the period of the study were included in the study. At the end of the study, it was determined in the power analysis that effect size was 1.54 and power was 0.99 at significance level of 0.05 and confidence interval of $95 \%$ which indicated that the sample was sufficient. The people who did not receive any training on hypertension before, were over the age of 30, were receiving hypertension treatment for at least 1 year, who were on medication for at least 1 year, were open to communicate, voluntary to participate in the study, and were able to answer the data collection tools in physical and mental terms were included in the study.

\section{Data Collection Tools}

A descriptive questionnaire containing general information about the socio-demographic characteristics and diseases of patients prepared by the researcher reviewing the similar studies and MMAS-8 Items were used to collect the data. In this questionnaire, there are a total of 31 questions in which the first 13 questions aim to determine the descriptive characteristics of the individuals, the next 4 question aim to determine the individual's habits, the next 2 questions check the status of having training about the hypertension diseases and the last 12 questions evaluate their hypertension status.

\section{Morisky Medication Adherence Scale (MMAS-8-Items)}

Morisky Medication Adherence Scale (MMAS-8Items) used for evaluating the patients' medication adherence status in hypertension treatment was developed by Donald Morisky et al., in 2003. Cronbach's alpha coefficient of Donald Morisky scale was determined as 0.83 and this scale determines the patients' behaviors of using medicines. The first 7 questions of the scale are scored as 0 for YES and 1 for NO answer. In 8 questions, 1-None/Rarely, 2-Occasionally, 3-Sometimes, 4-Usually and 5-Always options are given and one of them is expected to be answered. According to the patients' responses to the scale: they are evaluated as $<6$ Low adherence $6<8$ Medium adherence $=8$ High adherence ${ }^{15}$.

\section{Plan of the Study}

A pretest was firstly performed to the patients about their medication adherences and hypertension disease, then they were trained with the training form prepared by the researcher about the drug usage and general information and training brochures prepared by the researcher were handed out in order to ensure the permanence of the training. Afterwards, the posttest was carried out to assess the effectiveness of the training.

All the data were collected by using the face-to-face interview technique with individuals who agreed to participate in the study. Each interview lasted for averagely 30-45 minutes in a room where the individual would be comfortable. In the training, the patients were informed about hypertension disease, importance of drug in hypertension disease, importance of medication adherence in controlling blood pressure, and things to do by patients with hypotension for healthy life by using expository teaching technique. 
The training was strengthened by using the question-answer technique. The researcher delivered the training brochures to increase the permanence of the training and the patients were informed about next interview.

\section{Tests Used in the Study}

Statistical evaluations were performed by using Statistical Package for Social Science (SPSS) 13.0 program. In the evaluation of the data, pretest and posttest scores obtained from the scale and blood pressure measurement results were evaluated by using $\mathrm{t}$-test. In addition, in grouping made in terms of patients' gender, marital status, educational status, income status, family structure, hypertension years, status of having another chronic illnesses, status of using medications regularly and compliance to the diets, within-group comparison was made by using Wilcoxon Signed Rank Test and between-group comparison was made by using Mann Whitney U test in two groups and Kruskal-Wallis Test in three groups.

\section{Results}

In this study, it was found that the average age of the patients was $60.22 \pm 11.65(33-82)$. In addition, $\%$ 78.6 of the patients were female, $\% 25.7$ did not receive the training, \% 82.9 were married, $\% 74.3$ were housewives, $\% 55.7$ had an income equal to expenses, $\% 58.6$ had a nuclear family, and\% 88.6were smoker (Using averagely $19.16 \pm 12.01$ (5-40) per day) (Table 1).

Patients' hypertension duration was $8.47 \pm 7.92$ (130) years, and $\% 62.9$ of them had another chronic disease. When examining the other chronic diseases most commonly seen among the patients, it was found that the top three were diabetes mellitus (\% 18.6), hyperlipidemia (\% 11.4) and thyroid diseases (\% 8.6). Hypertension patients stated that $\%$ 34.3 used diuretics, \% 21.4 used ACE inhibitor and\% 10.0 used Ca channel blocker drug groups in order to provide the disease control and $\% 75.7$ used their medications regularly, \% 45.7 followed the diet given concerning the hypertension management. It was found that $\% 61.4$ of the patients had their own blood pressure device, but only\% 5.7 measured their blood pressure daily and almost half of them (\% 45.7) measured it when they felt discomfort. The patients stated that they were drinking lemon juice (\% 52.9), drinking blood pressure medicines (\% 37.1), going to emergency department (\% 35.7) and eating garlic (\% 24.3), respectively at home when their blood pressures increase (Table 2).

When the patients' adherences to the medication treatment were evaluated before and after the training according to Morisky Medication Adherence Scale, it was determined that $\% 35.7$ adhered the medication treatment at low level and\% 64.3adhered at moderate level before the training. It was found that low adherence decreased to\% 10.0, moderate adherence decreased to $\% 32.9$ and high adherence increased in more than half (\% 57.1) after the training (Table 3). In addition, it was determined in the statistical analysis that there was a significant increase between the mean scores before the training $(5.22 \pm 1.30)$ and after the training $(7.17 \pm 1.21)$ for Morisky Medication Adherence Scale and the difference between them was statistically significant at high level $(p<0.001)$. The planned training given to patients with hypertension was effective in their medication adherence (Table 3 and 4).

When mean systolic blood pressures of patients with hypertension were evaluated, it was found that the mean systolic blood pressure decreased after the training (126.42 \pm 21.47$)$ compared to the values before the training (138.14 \pm 22.98$)$, and the difference between them was statistically significant at high level $(p<0.001)$. When the mean diastolic blood pressure of patients with hypertension was evaluated, it was found that diastolic blood pressure decreased after the training $(73.42 \pm 10.75)$ compared to values before the training $(80.42 \pm 12.21)$, and the difference between them was statistically significant at high level $(p<0.001)$. It was determined that the planned training given to patients with hypertension was effective in decreasing the blood pressure of patients (Table 4).

Table 5 shows the mean scores obtained by the patients with hypertension from the MMAS before and after the training according to some of their socio-demographic characteristics. The mean scores obtained by the patients with hypertension from the MMAS before and after the training increased in statistically significant level $(\mathrm{p}<0.05)$, this decrease in the scores did not show a difference in terms of the patients' gen$\operatorname{der}(\mathrm{z}=-0.811, \mathrm{p}=0.418)$, marital status $(\mathrm{z}=-1.590$, $\mathrm{p}=0.112)$, educational status $\left(\mathrm{X}^{2}=2.947, \mathrm{p}=0.567\right)$, income status $\left(\mathrm{X}^{2}=1.480, \mathrm{p}=0.477\right)$ and family structure $(\mathrm{z}=-0.446, \mathrm{p}=0.656)$ (Table 5). 
Table 1. Socio-demographic characteristics of patients with hypertension

\begin{tabular}{|c|c|c|}
\hline Socio-demographic characteristics & $\mathbf{n}$ & $\%$ \\
\hline Average age & \multicolumn{2}{|c|}{$60.22 \pm 11.65(33-82)$} \\
\hline \multicolumn{3}{|l|}{ Gender } \\
\hline Female & 55 & 78.6 \\
\hline Male & 15 & 21.4 \\
\hline \multicolumn{3}{|l|}{ Marital status } \\
\hline Married & 58 & 82.9 \\
\hline Single & 11 & 1.4 \\
\hline Widow & 1 & 15.7 \\
\hline \multicolumn{3}{|l|}{ Educational status } \\
\hline Illiterate & 18 & 25.7 \\
\hline Literate & 15 & 21.4 \\
\hline Primary school & 14 & 20.0 \\
\hline Secondary school & 9 & 12.9 \\
\hline High school & 14 & 20.0 \\
\hline \multicolumn{3}{|l|}{ Profession } \\
\hline Civil servant & 2 & 2.9 \\
\hline Craftsman & 3 & 4.3 \\
\hline Retired & 13 & 18.6 \\
\hline Housewife & 52 & 74.3 \\
\hline \multicolumn{3}{|l|}{ Income status } \\
\hline More & 7 & 10.0 \\
\hline Equal & 39 & 55.7 \\
\hline Less & 24 & 34.3 \\
\hline \multicolumn{3}{|l|}{ Family structure } \\
\hline Nuclear & 41 & 58.6 \\
\hline Extended & 29 & 41.4 \\
\hline \multicolumn{3}{|l|}{ Smoking } \\
\hline No & 62 & 88.6 \\
\hline Yes & 8 & 11.4 \\
\hline Average number of cigarettes per day & \multicolumn{2}{|c|}{$19.16 \pm 12.01(5-40)$} \\
\hline
\end{tabular}

Table 6 shows the mean scores obtained by the patients with hypertension from the MMAS before and after the training according to some of their disease and treatment-related characteristics. The mean scores obtained by the patients from the MMAS before and after the training increased in statistically significant level $(\mathrm{p}<0.05)$, this decrease in the scores did not show a difference in terms of the patients' hypertension duration $\left(X^{2}=1.282, \mathrm{p}=0.527\right)$, status of having another chronic disease $(z=-0.052, p=0.959)$, regular use of medications $(\mathrm{z}=-0.995, \mathrm{p}=0.320)$ and status of following the hypertension $\operatorname{diet}(\mathrm{z}=-0.286$, $\mathrm{p}=0.775)$ (Table 6).
Table 2. Disease and treatment-related characteristics of the patients

\begin{tabular}{|c|c|c|}
\hline Disease characteristics & $\mathbf{n}$ & $\%$ \\
\hline Mean hypertension duration (year) & \multicolumn{2}{|c|}{$8.47 \pm 7.92(1-30$} \\
\hline \multicolumn{3}{|l|}{ Other chronic diseases } \\
\hline No & 26 & 37.1 \\
\hline Yes & 44 & 62.9 \\
\hline \multicolumn{3}{|l|}{ Chronic diseases } \\
\hline Diabetes Mellitus & 13 & 18.6 \\
\hline Hyperlipidemia & 8 & 11.4 \\
\hline Thyroid diseases & 6 & 8.6 \\
\hline Osteoporosis & 3 & 4.3 \\
\hline Heart disease & 3 & 4.3 \\
\hline Asthma & 3 & 4.3 \\
\hline Rheumatism & 2 & 2.9 \\
\hline Varicosis & 1 & 1.4 \\
\hline Bronchitis & 1 & 1.4 \\
\hline Renal failure & 1 & 1.4 \\
\hline Hepatic lipidosis & 1 & 1.4 \\
\hline Herniated disc & 1 & 1.4 \\
\hline Brain tumor & 1 & 1.4 \\
\hline \multicolumn{3}{|l|}{ Drugs used } \\
\hline \multicolumn{3}{|l|}{ Diuretic } \\
\hline Yes & 24 & 34.3 \\
\hline No & 46 & 65.7 \\
\hline \multicolumn{3}{|l|}{ ACE inhibitor } \\
\hline Yes & 15 & 21.4 \\
\hline No & 55 & 78.6 \\
\hline \multicolumn{3}{|l|}{ Ca channel blockers } \\
\hline Yes & 7 & 10.0 \\
\hline No & 63 & 90.0 \\
\hline \multicolumn{3}{|l|}{ Regular medication use } \\
\hline No & 17 & 24.3 \\
\hline Yes & 53 & 75.7 \\
\hline \multicolumn{3}{|l|}{ Having blood pressure device } \\
\hline No & 27 & 38.6 \\
\hline Yes & 43 & 61.4 \\
\hline \multicolumn{3}{|l|}{ Blood pressure measurement frequency } \\
\hline Everyday & 4 & 5.7 \\
\hline Every other day & 4 & 5.7 \\
\hline Once a week & 9 & 12.9 \\
\hline When feeling discomfort & 32 & 45.7 \\
\hline Rarely & 21 & 30.0 \\
\hline \multicolumn{3}{|l|}{ Following HT diet } \\
\hline Yes & 32 & 45.7 \\
\hline No & 38 & 54.3 \\
\hline \multicolumn{3}{|c|}{ What do you do first when your blood pressure goes up * } \\
\hline I drink lemon juice & 37 & 52.9 \\
\hline I take my high blood pressure medication & 26 & 37.1 \\
\hline I go to the emergency department & 25 & 35.7 \\
\hline I eat garlic & 17 & 24.3 \\
\hline
\end{tabular}

$\mathrm{n}$, number; ACE, angiotensin-converting enzyme; $\mathrm{Ca}$, calcium; $\mathrm{HT}$, hipertansion. 
Table 3. Patients' medication adherence status before and after the training

\begin{tabular}{lcccc}
\hline \multirow{2}{*}{ MMAS } & \multicolumn{2}{c}{ Before the training } & \multicolumn{2}{c}{ After the training } \\
\cline { 2 - 5 } & $\mathrm{n}$ & $\%$ & $\mathrm{n}$ & $\%$ \\
\hline Low adherence $(<6)$ & 25 & 35.7 & 7 & 10.0 \\
Moderate adherence $(6,<8)$ & 45 & 64.3 & 23 & 32.9 \\
High adherence $(8)$ & 0 & 0.0 & 40 & 57.1 \\
\hline
\end{tabular}

$\mathrm{n}$, number; MMAS, Morisky medication adherence scale.

Table 4. Comparison of the patients' scale scores and mean blood pressures before and after the training

\begin{tabular}{|c|c|c|c|c|}
\hline Variables & $\begin{array}{c}\text { Before the training } \\
X \pm S D \\
\text { (min-max) }\end{array}$ & $\begin{array}{c}\text { After the training } \\
X \pm \text { SD } \\
\text { (min-max) }\end{array}$ & $\begin{array}{l}\text { t-test } \\
\text { value }\end{array}$ & $p$ \\
\hline $\begin{array}{l}\text { Mean score } \\
\text { of MMAS }\end{array}$ & $\begin{array}{l}5.22 \pm 1.30 \\
(0-6)\end{array}$ & $\begin{array}{c}7.17 \pm 1.21 \\
(3-8)\end{array}$ & -11.261 & 0.000 \\
\hline $\begin{array}{l}\text { Systolic } \\
\text { blood pressure }\end{array}$ & $\begin{array}{c}138.14 \pm 22.98 \\
(90-220)\end{array}$ & $\begin{array}{c}126.42 \pm 21.47 \\
(90-180)\end{array}$ & 4.625 & 0.000 \\
\hline $\begin{array}{l}\text { Diastolic } \\
\text { blood pressure }\end{array}$ & $\begin{array}{c}80.42 \pm 12.21 \\
(60-100)\end{array}$ & $\begin{array}{c}73.42 \pm 10.75 \\
(60-100)\end{array}$ & 5.655 & 0.000 \\
\hline
\end{tabular}

\section{Discussion}

Hypertension is a chronic disease that can cause damage to all organs and cannot completely be treated. However, its damages can be minimized with the patient's adherence to the treatment. Reasons behind why blood pressure cannot be reduced to the desired levels in hypertension are the failure of having adaptation to medication to control blood pressure and having compliance to treatment ${ }^{16}$. Patient's adherence to the treatment plan determined in enhancing the quality of life of patient and in the successful treatment of hypertension is important ${ }^{17}$. There are many purposes for the training programs given to patients with hypertension. One of these purposes is to ensure the patients to use medications correctly and teach them the applications required to maintain blood pressure at normal levels. It was determined in the present

Table 5. The scores obtained by the patients with hypertension from the MMAS before and after the training according to some of their socio-demographic characteristics

\begin{tabular}{|c|c|c|c|c|}
\hline $\begin{array}{l}\text { Socio-demographic } \\
\text { characteristics }\end{array}$ & $\begin{array}{l}\text { Before the training } \\
\qquad X \pm S D\end{array}$ & $\begin{array}{l}\text { After the training } \\
\qquad X \pm S D\end{array}$ & $\begin{array}{l}\text { Variance } \\
\mathrm{X} \pm \mathrm{SD}\end{array}$ & $\begin{array}{c}\text { Test } \\
\text { Wilcoxon }\end{array}$ \\
\hline \multicolumn{5}{|l|}{ Gender* } \\
\hline Female & $5.12 \pm 1.38$ & $7.05 \pm 1.23$ & $1.92 \pm 1.60$ & $z=-5.868, p=0.001$ \\
\hline Male & $5.60 \pm 0.91$ & $7.60 \pm 1.05$ & $2.00 \pm 0.53$ & $z=-3.571, p=0.001$ \\
\hline Mann-Whitney U Test & & $\mathrm{U}=-0.811, p=0.418$ & & \\
\hline \multicolumn{5}{|l|}{ Marital Status* } \\
\hline Married & $5.18 \pm 1.36$ & $7.25 \pm 1.16$ & $2.06 \pm 1.42$ & $z=-6.419, p=0.001$ \\
\hline Single & $5.41 \pm 0.99$ & $6.75 \pm 1.42$ & $1.33 \pm 1.43$ & $z=-2.319, p=0.020$ \\
\hline Mann-Whitney U Test & & $U=-1.590, p=0.112$ & & \\
\hline \multicolumn{5}{|l|}{ Educational Status ${ }^{\star \star}$} \\
\hline Illiterate & $5.16 \pm 1.42$ & $7.22 \pm 1.16$ & $2.05 \pm 0.34$ & $z=-3.669, p=0.001$ \\
\hline Literate & $4.66 \pm 1.79$ & $7.00 \pm 1.46$ & $2.33 \pm 0.44$ & $z=-3.238, p=0.001$ \\
\hline Primary school & $5.28 \pm 1.06$ & $7.42 \pm 0.85$ & $2.14 \pm 0.37$ & $z=-3.222, p=0.001$ \\
\hline Secondary school & $5.33 \pm 1.11$ & $6.66 \pm 1.22$ & $1.33 \pm 0.33$ & $z=-2.401, p=0.016$ \\
\hline High school & $5.78 \pm 0.57$ & $7.35 \pm 1.33$ & $1.57 \pm 0.35$ & $z=-2.980, p=0.003$ \\
\hline Kruskal-Wallis Test & & $X^{2}=2.947, p=0.567$ & & \\
\hline \multicolumn{5}{|l|}{ Income status ${ }^{\star \star}$} \\
\hline Higher & $5.00 \pm 1.00$ & $7.14 \pm 0.89$ & $2.14 \pm 1.21$ & $z=-2.264, p=0.024$ \\
\hline Equal & $5.51 \pm 1.04$ & $7.25 \pm 1.22$ & $1.74 \pm 1.46$ & $z=-5.027, p=0.001$ \\
\hline Lower & $4.83 \pm 1.65$ & $7.04 \pm 1.30$ & $2.20 \pm 1.55$ & $z=-4.141, p=0.001$ \\
\hline Kruskal-Wallis Test & & $X^{2}=1.480, p=0.477$ & & \\
\hline \multicolumn{5}{|l|}{ Family structure* } \\
\hline Nuclear & $5.17 \pm 1.32$ & $7.12 \pm 1.28$ & $1.95 \pm 1.51$ & $z=-5.184, p=0.001$ \\
\hline Extended & $5.31 \pm 1.31$ & $7.24 \pm 1.12$ & $1.93 \pm 1.36$ & $z=-4.526, p=0.001$ \\
\hline Mann-Whitney U Test & & $z=-0.446, p=0.656$ & & \\
\hline
\end{tabular}

SD, standard deviation. 
Table 6. The mean scores obtained by the patients with hypertension from the Morisky Medication Adherence Scale before and after the training according to some of their disease and treatment-related characteristics

\begin{tabular}{|c|c|c|c|c|}
\hline $\begin{array}{l}\text { Disease } \\
\text { characteristics }\end{array}$ & $\begin{array}{c}\text { Before the training } \\
\quad \mathrm{X} \pm \mathrm{SD}\end{array}$ & $\begin{array}{c}\text { After the training } \\
X \pm S D\end{array}$ & $\begin{array}{c}\text { Variance } \\
\mathrm{X} \pm \mathrm{SD}\end{array}$ & $\begin{array}{c}\text { Test } \\
\text { Wilcoxon }\end{array}$ \\
\hline \multicolumn{5}{|l|}{ Hypertension year } \\
\hline $1-5$ year $(\mathrm{s})$ & $5.00 \pm 1.49$ & $7.02 \pm 1.31$ & $1.72 \pm 1.36$ & $Z=-4.837, p=0.001$ \\
\hline $6-11$ years & $5.38 \pm 1.19$ & $7.11 \pm 1.23$ & $2.00 \pm 1.09$ & $Z=-3.501, p=0.001$ \\
\hline 12 years and more & $5.56 \pm 0.89$ & $7.56 \pm 0.89$ & $2.02 \pm 1.62$ & $Z=-3.439, p=0.001$ \\
\hline Kruskal-Wallis Test & & $X^{2}=1.282, p=0.527$ & & \\
\hline \multicolumn{5}{|l|}{ Other chronic illness } \\
\hline No & $5.23 \pm 1.17$ & $7.07 \pm 1.29$ & $1.94 \pm 1.44$ & $Z=-3.951, p=0.001$ \\
\hline Yes & $5.22 \pm 1.39$ & $7.22 \pm 1.17$ & $1.62 \pm 0.48$ & $Z=-5.620, p=0.001$ \\
\hline Mann-Whitney U Test & & $z=-0.052, p=0.959$ & & \\
\hline \multicolumn{5}{|c|}{ Regular use of medications } \\
\hline No & $4.23 \pm 1.75$ & $6.70 \pm 1.57$ & $1.84 \pm 1.48$ & $Z=-3.541, p=0.001$ \\
\hline Yes & $5.54 \pm 0.95$ & $7.32 \pm 1.05$ & $2.00 \pm 1.43$ & $Z=-5.898, p=0.001$ \\
\hline Mann-Whitney U Test & & $z=-0.995, p=0.320$ & & \\
\hline \multicolumn{5}{|l|}{ Following HT diet } \\
\hline No & $5.16 \pm 1.42$ & $7.11 \pm 1.34$ & $1.94 \pm 1.44$ & $Z=-5.228, p=0.001$ \\
\hline Yes & $5.33 \pm 1.10$ & $7.25 \pm 0.98$ & $2.03 \pm 0.59$ & $Z=-4.459, p=0.001$ \\
\hline Mann-Whitney U Test & & $z=-0.286, p=0.775$ & & \\
\hline
\end{tabular}

study that patients' mean scores from MMAS before and after the training increased in statistically significant level, there was a significant increase between the mean scores before $(5.22 \pm 1.30)$ and after the training (7.17 \pm 1.21$)$ for MMAS and the difference between them was statistically significant at high level $(p<0.001)$. Planned training given to patients with hypertension was determined to be effective in their medication adherence.

In a study conducted by Bell and Kravitz, the healthy lifestyle behaviors were determined to be effective in developing the medication adherence via counseling training given by physicians ${ }^{14}$. In another study, MMAS score determined in the control three months later was determined to be significantly higher after the training compared to the value before the training ${ }^{17,18}$ determined in their study that the decreases in systolic blood pressure and diastolic blood pressure with a training program given to patients with hypertension were statistically significant ${ }^{19}$ found in their study that while the medicine use status of patients with hypertension was\% 73.3 before the training, this rate increased up to $100 \%$ after the training. In a similar study, the training given about developing medication adherence and healthy lifestyle behaviors was reported to cause a more significant increase in affecting the medication adherence change ${ }^{20}$. It was also determined in similar studies that the training increased the medication adherence ${ }^{20,21}$. These studies support the present study. In all of these studies, the applied training was observed to be important in preventing complications of hypertension disease and increasing regular medication use and medication adherence and to be effective for the blood pressure to be at normal levels. High adherence rate before the training compared to the adherence rate after the training makes us think that the training on hypertension given to individuals was effective and raising awareness in patients is important in increasing the medication adherence.

In another study, when the mean blood pressure values before and after counseling training given to coronary artery patients were compared, there was a decrease in diastolic blood pressure values after counseling training but no decrease was observed in systolic blood pressure values $^{22}$. The difference of that study from our study was that no training was given for medication adherence but only training about changing the lifestyle was given. Having no decrease in systolic blood pressure may be associated with this cause. It is thought here that only training about changing the lifestyle is not enough and also patients should use their medication regularly so that they can cause the systolic blood pressure to decrease. 
Hypertension disease threatens human health in Turkey and in the world. The first goal of hypertension treatment in terms of community health is to reduce the morbidity and mortality rates that will develop due to cardiovascular, renal and cerebrovascular causes. As long as blood pressure becomes normal in hypertension treatment, the possibility of development of the complications decreases significantly. Training given to hypertension patients plays an important role in increasing patients' medication adherence and reducing blood pressure to normal levels. Controlling hypertension is possible through team work. Therefore, all members of the healthcare team are responsible for providing full and exact information to the patients for having a healthy lifestyle, having blood pressure values at normal levels, using the medications regularly, and raising their awareness. Giving health trainings to people before the disease for the purpose of protecting from the disease will decrease the incidence of hypertension disease.

Consequently, one of the most important factors in following up and controlling hypertension is the patient's adherence to treatment. For this purpose, it is suggested to organize health education programs to patients in primary health care institutions, to use mass media to reach large masses while giving education, make them to watch instructive videos in waiting rooms and also to extend the studies conducted with similar training programs.

\section{References}

1. Poulter NR, Prabhakaran D, Caulfield M. Hypertension. Lancet 2015;27 0140-6736.

2. Laffin LJ, Bakris GL. Hypertension and new treatment approaches targeting the sympathetic nervous system. Curr Opin Pharmacol 2015;21:20-24.

3. Chobanian AV, Bakris GL, Black HR, Cushman WC, Green LA, Izzo JL Jr, et al. Seventh report of the Joint National Committee on Prevention, Detection, Evaluation, and Treatment of High Blood Pressure. Hypertension 2003;42:1206-1252.

4. Bakoğlu, E, Yetkin, A. The evaluation of self-care agency of with hypertansion patients. C. Ü. Hemşirelik Yüksekokulu Dergisi 2000;4:41-49.

5. Mancia G, Fagard R, Narkiewicz K, Redon J, Zanchetti A, Böhm M et. al. Guidelines for the Management of Arterial HypertensionTheTask Force for the Management of Arterial Hypertension of the European Society of Hypertension (ESH) and of the European Society of Cardiology (ESC). Journal of Hypertension 2013;31(7):1281-357.

6. Mert H. A multidisciplinary special study module research: treatment compliance of patients with hypertension. Türkiye Aile Hek Derg 2010;15:17-12.
7. Mancia G, De Backer G, Dominiczak A, Cifkova R, Fagard R, Germano $\mathrm{G}$, et al. A guide to the treatment of arterial hypertension 2007. Türk Kardiyol Dern Res 2007;35 Suppl 3:1-75.

8. Arıcı M, Çağlar Ş. Hypertension and its problems. Hacettepe Medical Journal 2002;33(1):4-9.

9. Hacıhasanoğlu, R. Treatment Compliance Affecting Factors in Hypertension. TAF Preventive Medicine Bulletin 2009;8(2):167-172.

10. Gün Y, Korkmaz M. Treatment adaptation and Quality of life of hypertensive patients. DEUHYO ED 2014;7(2):98-108.

11. Şarlı, Ş. "Adaptation to Treatment, Affecting Factors and Quality of Life in Patients with Hypertension Disease esi, Thesis in Medicine, Erciyes University Faculty of Medicine Department of Public Health, 2011.

12. Mancia G, Backer GD, Dominiczak A, Cifkova R, Fagard R, Germano $G$ et al. Guidelines for the management of arterial hypertension: The Task Force for the management of arterial hypertension of the European Society of Hypertension (ESH) and of the European Society of Cardiology (ESC). J Hypertension 2007;31:1281-357.

13. Cingil D. Evaluation of compliance and level of knowledge of patients with hypertension living in Karaman city center, Turkey. Arch Turk Soc Cardiol 2009;37(8):551-556.

14. Bell RA, Kravitz RL. Physician Counseling for Hypertension: What Do Doctors Really Do? Patient Education and Counseling 2008;(72):115-121.

15. Hacıhasanoğlu R, Gözüm S, Çapık C. Validity of the Turkish version of the medication adherence self-efficacy scaleshort form in hypertensive patients. Anadolu Kardiyol Derg 2012;12:241-248.

16. Şahin, ŞN. The Effect of Patient Adaptation in Patients with Hypertension Management and an Initiative for the Understanding of Patients' Health. Adnan Menderes University Faculty of Medicine Department of Family Medicine, Thesis, 2014.

17. Graves JW. Management of diffucult to control hypertension. Mayo Clinic Proceedings 2000;75:278-284.

18. Xu LJ, Meng Q, He SW, Yin XL, Tang ZL, Bo HY et al. The Effects of health education on patients with hypertensiyon in China, a Meta-Analsis. Health Education Journal 2014;73:137149 .

19. Çakır, H. The effect of education given to patients with hypertension on healthy lifestyle behaviors and hypertension management ert Master Thesis, Marmara University Institute of Health Sciences, Istanbul, 2003.

20. Taş F. Hypertension Awareness and Role of the Nurse. TAF Prev Med Bull 2013;12(6):729-734.

21. Ni Y, Chen Y, Huang W. The Effects of Pharmaceutical Care Programs on Blood Pressure Control in İndividuals With Hypertension, a Meta-Analsis, The Journal of Pharmacy and Tecnology 2009;25:292-296.

22. Kuçer AM, Özbay A. Efects of patient education and counseling about life style on quality of life in patients with coronary artery disease. Anadolu Kardiyol Derg 2011;1:107-113. 